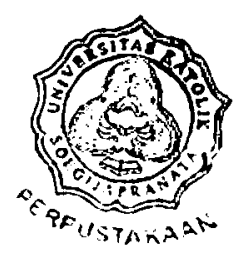

\title{
THE IDEOLOGY AND THE IDEATIONAL MEANING PROCESSES BEHIND THE ADVERTISEMENTS OF COSMOPOLITAN MAGAZINE'
}

\section{Cicilia San San ${ }^{2}$, Heny Hartono, and Angelika Riyandari ${ }^{3}$}

\begin{abstract}
This study tried to reveal the ideology and the process of ideational meaning behind the advertisements found in a female magazine. Cosmopolitan. The analysis of ideology was hased on four basic asstmptions. They are beauty, prestige, health and others. In analyzing the processes of the ideational meaning, the writer used Halliday theory that discusses about six types of processes. They are material (doing/event) process. mental (thinking/ sensing/feeling) process, relational (attributive/ identifying) process, behavioral process. verhal process and existential process. The results show that the advertisements are dominaled by beanty ideology $(45.5 \%)$ and relational process $(41.4 \%)$. Based on the result, it is clear that as a female magazine. Cosmopolitan prescents adiertisements that offer beaury products/ senices. Moreover, relutional process (identifying) is used mone becanse the producer and the advertiser are aw are that they cannot compel the comsumers to bu the products senvices offered. The use of the process is aimed to show the products senvices that will rasise the currosity of the consumers and to perstuade the consumers tobutheproducts somices.
\end{abstract}

Key words: Adrerriseme'nt's ants. ideology: processces of ideational meaning. Iransitivity șistems.

This article is a development of the thesis defended at the Jaculty of Letters. Soegijapranata Catholic University. Semarang.

Cecilia San San, S.S. <ceciliasansan (a yahoo.com> is an alumnae of the Faculty of l.etters. Soegijapranata Semarang and currently an education stalf at the Centre for Language Training Soegijapranata Catholic University. Se'marang

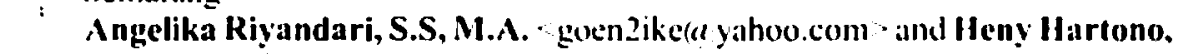
.Pd. Chenyhartono (a yalioo.com>are lecturers of the laculty of l.ellers. upramata Catholic University. Semarang 


\section{BACKGROUND}

In this modern erat, advertisement has become a part of people's life. Fvery time and everywhere, people often see or hear advertisements. For example, when people go to public places, such ats mall. market, public transportation station; people will casily find advertisements there. Advertisements can also be found in more private medial such as TV, magazines and newspaper. In fact, nowadays, advertisements can be found in various mass media.

Through the advertisements, the producers introduce their products as well as persuading people to buy their products. The Institute of Practitioner in Advertising as cited by Jefkins (1994:5) states that "Advertising presents the most persuasive possible selling message to the right prospects for the product or service at the lowest possible cost". This statement has triggered the writers' curiosity to analyze the factors behinds the advertisement texts such as the idcology and the processes of ideational meanings which make the advertisement's texts easily accepted by the community. 112 advertisements clauses that are taken from 3 editions of Cosmopolitan magazinc on March, August and September 2005 were used as the representative and the source of data. By applying the Systemic Functional Grammar, that is a system which is based on the meaning, the processes of ideational meaning and the ideology will be revealed.

In this study, the writer used the data from female magazine. According to Ibrahim and Suranto (1998:117, 118):

Majalah wanita, majalah lang mempunyai tugas khusus, yaitu menciptakan dumia yang khas untuk n'anita.

[Women magazine is a magazine that has special job. that is to create special world for women.]

Beherapa rubrik yung selalu terdapar dalam majalah wamita. vailit tentang resep-resep makanan. pendidikan. keschasan. kecantikan. dan mode.

[Some articles which are always found in women magazine. such as the food recipes, education, health. beauty, and fashion.]

It is an ideal magazine as data because the target market is women. It is very popular among people in the world, including in Indonesia. In the 
discussion about Konstruksi Identitas Perempuan dalam Majalah Cosmopolitan Indonesia, Leiliyanti (2003:69) states that, "Fun fearless female adalah slogan yang selalu melekat pada majalah Cosmopolitan ...." [Fun fearless female is a slogan which is always attached to Cosmopolitan magazine .... . Moreover, the layout of the magazine is very interesting with colorful cover and nice proportion in every page. The magazine is aimed for working people, with an achievable price, i.e. 29.000 rupiahs.

\section{RESEARCH QUESTIONS}

In this article, the writer aims to answer the following questions:

1. What are the ideologies mostly found in the advertisements of Cosmopolitan magazine?

2. What are the processes found in the advertisements of Cosmopolitan magazine?

To answer those questions, the data were analyzed using the systemic functional grammar to find the ideology and the processes used in the advertisements.

\section{IDEOLOGY IN THE ADVERTISEMENTS}

Eriyanto (2001:87-88) states that ideology is a belief system that belongs to a certain class. A group of people usually has its own vision. It cannot be changed because it has been rooted in people's mind. As the writers discuss ideology in the advertisement's texts as usually containing language or symbols, in fact ideology has relation to language as Fairclough's statement below:

One aspect of the imbrications in the social which is inherent to the notion of discourse is that language is a material form of ideology, and language is invested by ideology (1995:73).

The statement suggests that language appears because there is an ideology in mind. According to Fairclough:

The sociologist Harold Garfinkel has written of 'the familiar common sense world of everyday life', a world which is built entirely upon assumptions and expectations which control 
both the actions of members of society and their interpretation of the actions of others (1989:77).

The statement above highlights the assumptions and expectations that are familiar among people's everyday life. In relation to the ideology found in the advertisements of female magazine, there are four basic assumptions of ideology based on Fairclough's statement regarding the world as built up upon assumptions, i.e. the area of beauty, prestige, health and others. These four basic assumptions appear because of the influence of the society's belief. These four basic assumptions are also termed as the ideological common sense. Fairclough (1989:85,88) also states that,

ideologies in discourse are brought as the background assumptions which lead the producer and the interpreter to interpret the text by using their own way.

Ideological diversity is also called ideological common sense, whish comes from differences in position, experience and interests between social grouping.

For example, when Nur (2003:122) states, "Perempuan yang cantik harus berkulit putih, berambut lurus, bertubuh langsing, tidak berjerawat dan berbetis indah" [A beautiful woman has to have white skin, straight hair, slim body, no acnes and beautiful calves], Nur is said to highlight the ideological common sense of a woman. Most people agree with the opinion of how women are classified as beautiful. Due to this reason, beauty products are offered to help women achieve their beauty.

\section{PROCESSES OF IDEATIONALMEANING}

According to Martin and Rose (2001:59), "Ideation is concerned with how our experience of 'reality'-material and symbolic reality-is construed in discourse". For example, the question: 'What are you reading?' is directed to a person who is indicated as having an experience in reading. The questioner has had a concept of reading in mind. Reading is understood to involve the activity of opening a book/magazine/ newspaper, etc. and try to understand the content and the meaning of them. Eggins (1994:228) states: 


\begin{abstract}
Grammar of the clause is important when we look at the experiental metafunction. Whenever there is an exchange of the clause, we find there is one major system of grammatical choice involved in this kind of meaning. This is the system of TRANSITIVITY, or process type.
\end{abstract}

In this study, the writer focused on the ideational meaning processes. The processes makes a clause that has a certain meaning. Here, the writers use Halliday's theory to get further understanding of ideational meaning processes. According to Halliday (1994:109142), there are six types of processes described as follows:

a. Material processes: processes of doing in which every process has an actor and some processes have a second participant or goal. These processes have two subcategories, event and action, e.g.

The rain stopped. (event-happening)

She went to school. (action-doing)

b. Mental processes: processes of sensing in which they are distinguished into three subcategories: perception (related to the five senses), cognition (related to mind) and affection (related to feeling), e.g.

She saw the bird. (perception)

I forgot her name. (cognition)

He liked pop music. (affection)

c. Relational processes: processes of being, which are distinguished into two categories, attributive and identifying. Attributive means $a$ is an attribute of $x$. While identifying means $a$ is the identity of $x$, e.g.

She is beautiful. (attributive)

Dona is my sister. (identifying)

d. Behavioural processes: processes of (typically human) physiological and psychological behaviour, like breathing, coughing, smilling, dreaming and staring. They are located between material and mental processes. The boundaries of behavioural processes are indeterminate; but we can recognize the following kinds as typical:

1. [near mental] processes of consciousness represented as forms of behaviour, e.g. look, watch, stare, listen, think, worry, dream; 
2. [near verbal] verbal processes as behaviour, e.g. chatter, grumble. talk;

3. physiological processes manifesting states of consciousness, e.g. cry, laugh, smile, frown, sigh, snarl, whine;

4. other physiological processes, e.g. breathe, cough, faint, shit, yawn, sleep;

5. [near material] bodily postures and pastimes, e.g. sing, dance, lie (down), sit (up,down)

e. Verbal processes: processes of saying. These processes have two characteristics of mental and relation, e.g.

I'm thirsty.

I'm afraid.

f. Existential processes: representing something that exists or happens. These processes have two characteristics of relation and material, e.g.

There was a beautiful princess.

'There' represents that something, i.e. a beautiful princess exists.

\section{THE DEOLOGY FOUND IN THE ADVERTISEMENTS OF COSMOPOLITANMAGAZINE}

In this research, the writers focused more on the advertisement's texts as the data. As it has been mentioned in the background, the writers used 3 editions of Cosmopolitan magazine as representation. The data from Cosmopolitan magazines used English language. Each advertisement was segmented into clauses and analyzed using Transitivity System. Here are some clauses from the magazine as the example:

\begin{tabular}{|c|l|}
\hline No. & \multicolumn{1}{|c|}{ CLAUSE } \\
\cline { 2 - 2 } 1 & Ultima II \\
\hline 2 & $\begin{array}{l}\text { Get } \text { your firm, moothen, and soficn skin } \\
\text { instantly! }\end{array}$ \\
\hline & Fellice Jewelry \\
\cline { 2 - 2 } 3 & Shine your confidence. \\
\hline 4 & When luxury appears honestly. \\
\hline 5 & It's an imagine of a life perfection. \\
\hline
\end{tabular}

Table 1:

Ultima II and Felice Jewelry 
C. Sansan, H. Hartono and A. Riyandari, Ideology and Ideational Meaning 181

\begin{tabular}{|c|c|c|c|}
\hline System & Feanre & $\mathrm{N}$ & $\%$ \\
\hline \multirow{3}{*}{ IDEOLOGY } & Beauty & 51 & $45.5 \%$ \\
\cline { 2 - 4 } & Prestige & 41 & $36.6 \%$ \\
\cline { 2 - 4 } & Health & 9 & $8.0 \%$ \\
\cline { 2 - 4 } & Others & 11 & $9.8 \%$ \\
\hline
\end{tabular}

Table 2:

Ideology found in the advertisements

The result presented in the table above shows that beauty ideology is used more frequently in Cosmopolitan magazine. From the table, beauty ideology dominates $45.5 \%$ of all ideology categories. As it has been discussed before, Cosmopolitan magazine is a female magazine. Women do care about their beauty. Due to this reason, it is not surprising that the advertisements here offer products/services to promote the beauty of women, e.g.

\begin{tabular}{|l|l|l|l|l|}
\hline \multicolumn{1}{|c|}{ Kose } \\
\hline & Participant & \multicolumn{1}{|c|}{ Process } & \multicolumn{1}{c|}{ Goal } & Circumstance \\
\hline a & $\begin{array}{l}\text { Moisture Skin } \\
\text { Repair }\end{array}$ & is bom & & \\
b & It & is & $\begin{array}{l}\text { Rice Power Extract } \\
\text { no. } 11\end{array}$ & \\
skin's ability & to retain moisture \\
\hline
\end{tabular}

Table 3:

Kose

The prestige ideology is also found a lot in the advertisements of Cosmopolitan magazine. From the data, the writer found $36.6 \%$ of them. Prestige is an important thing for women if they want to be accepted in social intercourse, c.g.

BMW

\begin{tabular}{|c|l|l|l|}
\hline & \multicolumn{1}{|c|}{ Participant } & \multicolumn{1}{c|}{ Process } & \multicolumn{1}{c|}{ Goal } \\
\hline a & & Experience & $\begin{array}{l}\text { the next level } \\
\text { the new BMW 3 } \\
\text { series }\end{array}$ \\
\hline
\end{tabular}

Table 4:

BMW 
182 Celt, Volume 7, Number 2, December 2007: 175 - 188

Therefore, it is very clear that besides caring about their beauty, women also like to show their prestige.

Table 2 also shows that the lowest percentage $8.0 \%$ of ideology is found in health. Yet health is very important for all people. Even it has become a lifestyle for modern people. However, in Cosmopolitan magazine, the advertisements that reflect health ideology are just a few. It happens because Cosmopolitan magazine is a female magazine, it is not a health magazine. Suppose, Cosmopolitan is a health magazine, the advertisements that reflect health would be dominant. However, Cosmopolitan is a female magazine, so everything concerning with health is not discussed very often, i.e. just 9 clauses from 112 clauses.

Based on the explanation above, it proves that Cosmopolitan magazine is a female magazine that tries to exploit women's needs. It can be seen from the table that most of the advertisements in the magazine offer beauty and prestige products, as those two things are very important for women. In addition, producing women's products are very profitable for the producer. According to Ibrahim and Suranto (1998:317),

Para produsen menganggap perempuan cenderung punya tradisi konsumtif yang tinggi ... Mereka berbelanja, mulai dari keperluan sehari-hari, seperti bahan makanan dan minuman, sampai pada belanja barang untuk kecantikan dan kemewahan.

[The producers assume that women tend to have high consumptive tradition... They shop, from daily needs, such as food and drink, to beauty and luxury products.]

Chaney (1996:62) also states that, “... pusat-pusat perbelanjaan kian tergantung pada para pelanggan wanitanya ..." [... the shopping centers are depending more on their women customers ...]. Therefore, there are more and more female magazines presenting women product advertisements. 


\section{THE PROCESSES OF IDEATIONAL MEANING FOUND IN THE ADVERTISEMNETS OF COSMOPOLITAN MAGAZINE}

\begin{tabular}{|c|c|c|}
\hline Process & N & $\%$ \\
\hline Material & 32 & $28.8 \%$ \\
\hline Mental & 9 & $8.1 \%$ \\
\hline Relational & 66 & $59.4 \%$ \\
\hline Behavioural & 2 & $1.8 \%$ \\
\hline Verbal & 2 & $1.8 \%$ \\
\hline Existential & 1 & $0.9 \%$ \\
\hline
\end{tabular}

Table 5:

The Processes of Ideational meaning

\begin{tabular}{|c|c|c|c|}
\hline System & Fealure & $\mathrm{N}$ & $\%$ \\
\hline MATERIAL-TYPE & doing-active & 23 & $20.7 \%$ \\
\cline { 2 - 4 } & doing-passive & 6 & $5.4 \%$ \\
\cline { 2 - 4 } & Event & 3 & $2.7 \%$ \\
\hline & Thinking & 3 & $2.7 \%$ \\
\hline MENTAL-TYPE & Sensing & 3 & $2.7 \%$ \\
\hline & Feeling & 3 & $2.7 \%$ \\
\hline RELATIONAL-TYPE & Altributive & 20 & $18.0 \%$ \\
\hline & Identifying & 46 & $41.4 \%$ \\
\hline
\end{tabular}

Table 6:

The Features of the Processes of Ideational meaning

According to table 6 above, the relational process (identifying) gets the highest percentage, i.e. $41.4 \%$. Here are the explanations why the kind of process gets the highest percentage. The producers are aware that they cannot compel the consumers to buy the products/ services they have. Even though the advertisers have a lot of ways of persuading the consumer to buy the products, yet the decision of buying still becomes the consumers' authority. Therefore, the function of advertisement's texts is to show the products/ services offered. In other words, advertisements are used as a way to promote. Here, relational process (identifying) is appropriate if it is used 
in advertisement's text because the process is aimed to show the products/ services offered. By knowing the new products/services, it is hoped that the consumers will be attracted and buy the products/services.

Relational process (identifying) usually contains Token and Value. According to Halliday as cited in Eggins (2000:259-260), "... the Token will be a 'sign, name, form, holder or occupant' of a Value, which gives the 'meaning, referent, function, status or role' of the Token." For example in a HP advertisement:

\begin{tabular}{|c|c|c|c|}
\hline No. & Token & Process & Value \\
\hline 1 & It & Is & the new J200i \\
\hline
\end{tabular}

Table 7:

The new J200i

According to Halliday above, the word it in the advertisement is called "Token" and The New J200i is called "Value". It means that the word it has the same meaning with The New J200i.

The material process (doing-active) is also used a lot in the advertisements of Cosmopolitan magazine. According to Table 6 above, the writer found $20.7 \%$ for the process of all the data. Material process (doing) in advertisements is used to make the consumers realize that to reach something, they have to do something. For example, if a woman wants to have a fair skin, she has to do some efforts, such as undergoing skin treatment or using a certain skin product. Here is the example of a skin product advertisement's text:

\begin{tabular}{|c|l|l|l|}
\hline No. & \multicolumn{1}{|c|}{ Process } & \multicolumn{1}{c|}{ Goal } & Circumstance \\
\hline 1 & Get & $\begin{array}{l}\text { your firm, smoothen } \\
\text { and soften skin }\end{array}$ & Instantly \\
\hline
\end{tabular}

Table 8:

Get

By using the process in the advertisement's text, the producer persuades the consumers to buy the services/products offered. Hence, besides showing the products/services, most of the advertisement's texts are made in order to 
make the consumers undertake the process of buying. Here is the example of Felice jewclry advertisement's text:

\begin{tabular}{|c|c|l|l|}
\hline No. & Actor & \multicolumn{1}{|c|}{ Process } & \multicolumn{1}{c|}{ Goal } \\
\hline 1 & & shine & your confidence \\
\hline
\end{tabular}

Table 9:

Shine

The example of the advertisement's text above uses a word shine as the process. Using the word, the advertiser would like to persuade the consumer to do something, i.e. buying the jewelry if they want to get confidence. This idea is supported by Eggins (1994:230) who states that, "The basic meaning of material processes is that some entity does something, undertakes some action."

The existential process is rarely found in the data. The existential process in the advertisements indicates that the new products have been produced. Even though relational (identifying) and existential processes have the same aim, that is to show the product offered, both of them give different effect to the consumer. The existential process in the advertisement's text is used to show the product to the consumer without giving any direction to do the next action toward the product. Here the use of process is just to give information that certain product exists. Butt et. al. (2000:81) states that, "Existential processes are used to introduce the reader to people, places and things in the story world." Here is the example of the advertisement's text which uses the process:

\begin{tabular}{|c|l|l|l|}
\hline No. & & \multicolumn{1}{|c|}{ Process } & \multicolumn{1}{c|}{ Existent } \\
\hline 1 & There & is & no string attached \\
\hline
\end{tabular}

Table 10:

No string

The clause above is a part of a glasses advertisement's texts. Reading the clause above, people will easily understand that the advertisement introduces a new glasses product that does not use string. Sometimes, people do not give attention more if they are being introduced by something new or something which has not been too familiar. Due to the reason, using 
the process gives unprofitable effects to the producers because the curiosity of the consumers to buy the services/ products is not awakened.

Meanwhile as it has been discussed before, relational process (identifying) shows the point of referent. Here the product is shown directly to the consumers through the process. By showing off the product directly, the curiosity of people to know more about the product is bigger. Next, the curiosity will motivate the consumers to buy the services/ products offered. Based on the explanation above, it may be clear that existential process gets the lowest percentage, i.e. $0.9 \%$.

\section{CONCLUSION}

After classifying the data based on the processes of ideational meaning, the writer concludes that most of the advertisement's texts in Cosmopolitan magazine use relational process. There are two reasons why relational process is used more in the advertisements. Firstly, the relational process is used by the advertiser to show or promote the products or services offered. By showing the products/ services, it is hoped that the consumers are curious and then buy the products/ services offered. Secondly, the advertiser and the producer are aware that they cannot compel the consumers to buy the products/services they have. The decision of buying still becomes the authority of the consumers. Therefore, relational process is appropriate if it is used in the advertisement's texts.

The writer also concludes that most of the advertisements in the Cosmopolitan magazine reflect the beauty ideology. Besides presenting the advertisements that reflect beauty ideology, the magazine also presents a lot of advertisements that reflect prestige ideology. Since Cosmopolitan magazine is a female magazine, it is no wonder that most of the advertisements in the magazine discuss more about women's needs. As most people would believe, women always care about their physical performance. In addition, the perfect physical performance must be supported by beauty treatments. This is why beauty products/ services are offered through the magazine: cosmetics, perfume and beauty clinic. Similarly, prestige is also important for people in their social intercourse. Seeing this condition, people prefer to wear or use popular goods because 
they can increase people's prestige. Products/ services that are offered through the magazine and can raise people's prestige are jewelry, car, and mobile phone.

\section{BIBLIOGRAPHY}

Butt, David. et.al. "Using Functional Grammar". Sydney: Macquarie University, 2000.

Chaney, David. "Lifestyles". In Lifestyles: Sebuah Pengantar Komprehansif. Edited by Idy Subandy Ibrahim. Yogyakarta: Jalasutra, 1996.

Eggins, Suzane. “An Introduction to Systemic Functional Linguistics”. London: Pinter Publisher, 1994.

Eriyanto. "Analisis Wacana:Pengantar Analisis Teks Media". Yogyakarta: LkiS Yogyakarta, 2001.

Fairclough, Norman. "Language and Power". London \& New York: Longman, 1989.

. "Critical discourse analysis:the critical study of language". London:Longman, 1995.

Halliday, M.A.K. "An Introduction to Functional Grammar". London: Edward Amold, 1994.

Ibrahim, I.S. and Hanif Suranto .eds. "Wanita dan Media: Konstruksi Ideologi Gender dalam Ruang Publik Orde Baru". Bandung: Rosda, 1998.

Jefkins, F. “Advertising Third Edition". London: ME Handbook, 1994.

Leiliyanti, E. "Konstruksi Identitas Perempuan dalam Majalah Cosmopolitan Indonesia". In Jurnal Perempuan untuk Pencerahan dan Keselarasan. 2003: 28, 69-83.

Martin, J.R. and David Rose. "Working with Discourse". Sydney and Hong Kong: The State University of Semarang, 2001.

Nur R., T.H. "Stereotipe dan Komoditas Perempuan dalam Iklan". In Jurnal Perempuan untuk Pencerahan dan Keselarasan. 2003: 28, 119-128. 
188 Celt, Volume 7, Number 2, December 2007: 175 - 188

\section{APPENDIX}

\section{Transitivity System}

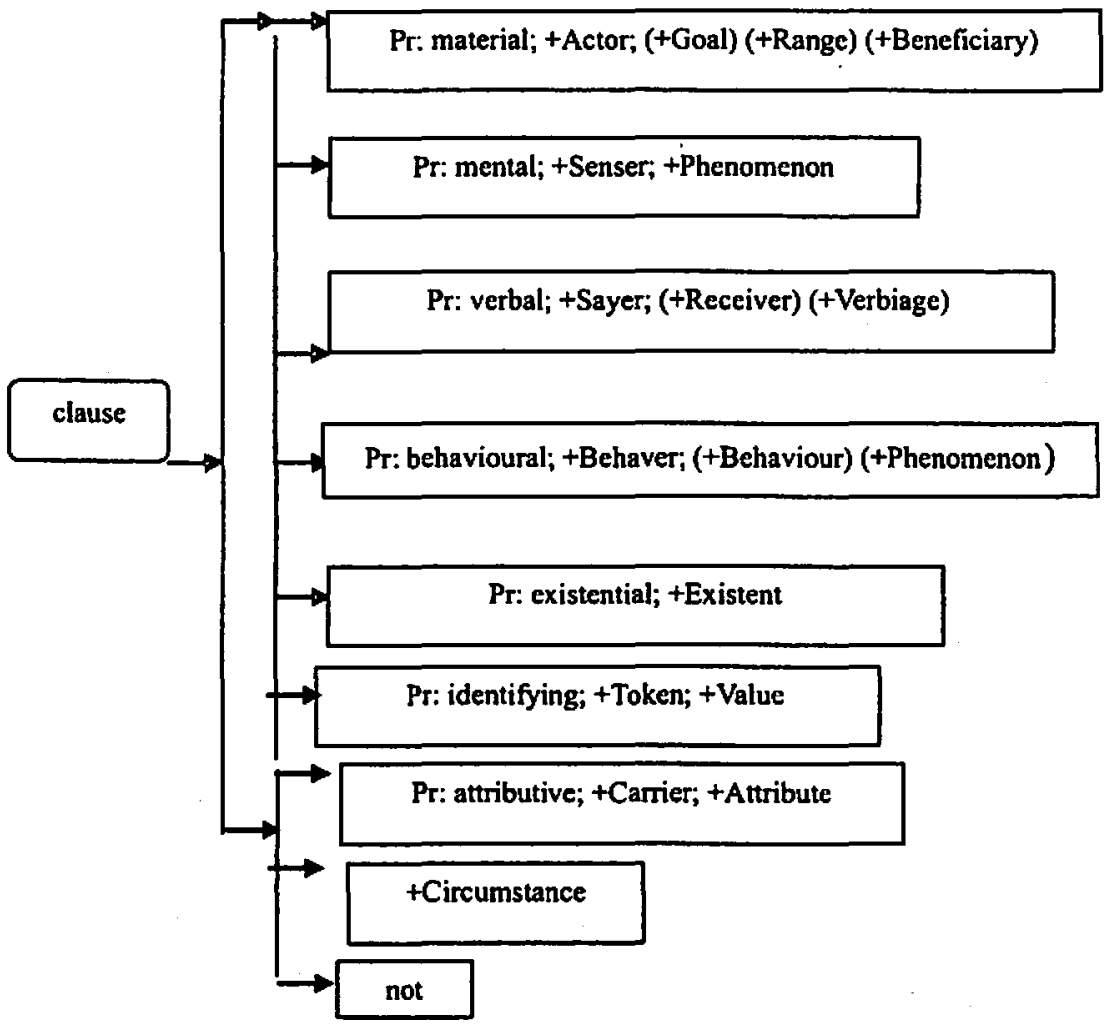

